\title{
Erratum to: 2014 World Forum on Biology_Joint Meeting of the Society for In Vitro Biology and the Society for Cryobiology, May 31-June 4, Savannah, Georgia
}

\section{Late Submission Abstracts}

Published online: 11 September 2014

(C) The Society for In Vitro Biology 2014

Erratum to: In Vitro Cell. Dev. Biol.-Plant

DOI 10.1007/s11627-014-9627-z

\section{Late Abstracts}

P-3000

Influence of Added Nutrients in the Fermentation Process of Sugar Cane and Sweet Sorghum Varieties for Ethanol Concentration. L. PARKS. Tuskegee University, 808-B Phillips Dr., Tuskegee, AL 36088. Email: 1parks3606@mytu.tuskegee.edu

The names of the following authors were omitted from the original abstract: Desmond G. Mortley, Marceline Egnin, and Moabin Tu. The correct address of affiliation for Lashachiah Parks, Desmond Mortley and Marceline Egnin is: George Washington Carver Agricultural Experiment Station and Department of Agricultural and Environmental Nutritional Sciences, Tuskegee University, Tuskegee AL 36088. The correct affiliation for Moabin $\mathrm{Tu}$ is: Auburn University NSF Bioenergy Program, Auburn, AL 36849. Desmond G. Mortley's email address was omitted from the original abstract. It is mortleyd@mytu.tuskegee.edu
P-3045

Expression Analysis of Salt Overly Sensitive 2 (SOS2) Gene Salt Stressed Tomato Plants. Ö. ÇELIK, B. Candar-Çakır, and S. Sinem. Istanbul Kültür Üniversity, Faculty of Science and Letters, Department of Molecular Biology and Genetics, Atakoy, Istanbul 01 34156, TURKEY. Email: ocelik@ iku.edu.tr

The author order was listed incorrectly in the original abstract. The correct order of authors is as follows:

Bilgin Candar Çakir, Saritaş Sinem, and ÖZGE ÇELIK

P-3046

Microencapsulation of Urtica dioica (from Aydin Region of Turkey) Leaf Extracts. Ö. ÇELIK and A. İnan. Istanbul Kültür Üniversity, Faculty of Science and Letters, Department of Molecular Biology and Genetics, Atakoy, Istanbul 01 34156, TURKEY. Email: ocelik@iku.edu.tr

The author order was listed incorrectly in the original abstract. The correct order of authors is as follows:

Ali Ínan and ÖZGE ÇELIK 